\title{
Nutritional Status and Health Characteristics of People Living with HIVIAIDS
}

\author{
Siti Ulfah Rifa'atul Fitri ${ }^{1}$, ${\text { Kusman } \text { Ibrahim }^{1 *} \text { D , Siti Sandra Liani }}^{1}$, Laili Rahayuwati ${ }^{2}$, Yusshy Kurnia Herliani ${ }^{1}$ (D) \\ ${ }^{1}$ Department of Medical Surgical Nursing, Faculty of Nursing, Universitas Padjadjaran, Bandung, Indonesia; ${ }^{2}$ Department of \\ Community Health Nursing, Faculty of Nursing, Universitas Padjadjaran, Bandung, Indonesia
}

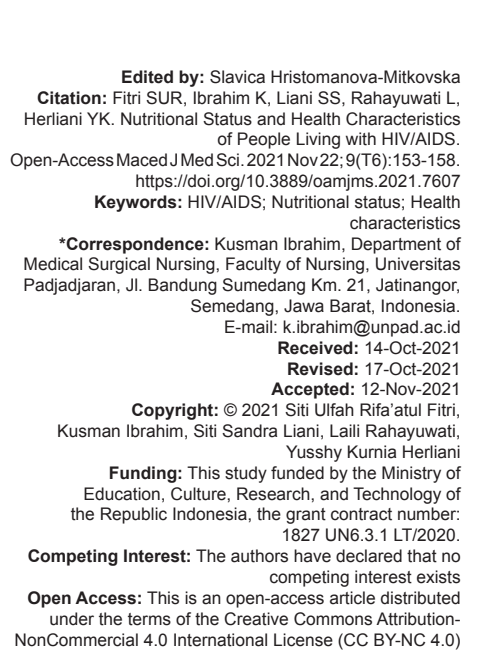

\section{Abstract}

BACKGROUND: Diagnosis and treatment of HIV infection may impact on the individual's life, including the physical aspect such as the length of HIV diagnosed, WHO stage, the antiretroviral therapy (ART), and the psychologica aspect such as the level of stress. People living with HIVIAIDS (PLWHA) have an increased need of energy but they have symptom of lack of nutrition intake. Therefore, PLWHA have a risk of low nutrition status.

AIM: The aims of this study were to examine the relationship between nutritional status and health characteristics among HIVIAIDS patients.

METHODS: A cross-sectional analytical design was conducted among PLWHA in outpatients' hospital. A purposive sampling method was used and the sample size was 78 respondents. Data relating to socio-demographic and health characteristics, and nutritional status were collected using questionnaires. The cross-tabulation calculations used Chi-square were presented to identify the relationship between nutritional status and health characteristics.

RESULTS: The majority of respondent had the good health characteristic which includes the length of HIV diagnosed more than 6 months (79.5\%), clinical WHO Stage I (61.5\%), no stress level (94.9\%), and first choice of ART (83.3\%). The nutritional status reported that majority of the respondents had normal body mass index (61.5\%), mid-upper arms circumstances not at risk $(>23.5 \mathrm{~cm})(71.8 \%)$, and moderate level of energy intake $(37.2 \%)$. There was no significant associated between the nutritional status and health characteristics $(p>0.05)$.

CONCLUSION: The good condition of health characteristic among PLWHA in this study impacted on level the nutritional status.

\section{Introduction}

The development of the HIV-AIDS epidemic is still a global problem, including in Indonesia. According to the database of the World Health Organization [1], in December 2016, there were 36.7 million people living with HIV of which 1.8 million were new cases. Southeast Asia was the second largest region after Africa by 3.5 million people. Whereas in Indonesia, the total number people living with HIVIAIDS (PLWHA) reported from October 1, 2016, until December 31, 2016, were 41,250 people, including 7491 people in phase of AIDS and 806 people died [2].

Diagnosis and treatment of HIV infection may impact on the individual's life, including physical, psychological, and social impacts. The physical impacts among PLWHAcan occur for the rest of their lives [3]. The trajectory illness of HIV was different for each individual. The time period between seroconversion (negative antibody status to positive) and the appearance of symptoms can occur around \pm 10 years which is called asymptomatic period. Then, it will continue into symptomatic phase when the level of CD4 decreased gradually until $<300$ cells $/ \mu$ l. The patient will experience symptoms that show immunosuppression and continue until the AIDS phase. Regarding psychological and social impacts, stigma and discrimination in the community are particularly relevant for PLWHA [3], [4], [5].

PLWHA shows different state of health condition, including physical and psychological condition. The physical condition such as the length of HIV diagnosed, the stage of HIV, type of anti-retroviral therapy (ART), as well as the psychological condition such as the level of stress. The immune system, HIV, and nutrition having many parts were usually interrelated. PLWHA have an increased need of energy, whereas the symptoms of HIV infection and opportunistic infections can reduce nutrient intake, whether caused by decreased appetite or difficulty swallowing, or the presence of malabsorption. These condition can cause malnutrition among PLWHA [6].

There are four causes of malnutrition among PLWHA: (1) Inadequate nutrient intake; (2) nutrient loss; (3) metabolic changes; and (4) increasing body needs. Even in the AIDS stage, patients can experience wasting syndrome, which is undesirable weight loss 
(more than $10 \%$ of basic body weight) and diarrhea or chronic weakness within 30 days, accompanied by persistent fever without any other disease [7], [8].

The Regional General Hospital (RSUD) of Bandung City is one of the government referral hospitals that provide services for HIVIAIDS patients. A total of 350 PLWHA were recorded as outpatients undergoing ART in November 2017. Based on a preliminary study, there are no objective data related to nutritional status and how patients' efforts in fulfilling nutritional needs. Measurement of nutritional status was done by weighing the patient's body weight when controlling once a month. The nutrition installation staff also explained that there was no nutrition consultation proposed by the Kemuning Poli (HIV Clinic) in the past 1 year.

Monitoring the nutritional status is part of nursing intervention, so nurses as health workers have a responsibility in helping patients to monitor, maintain, and/or improve the nutritional status. PLWHA who have a risk of experiencing nutritional disorders throughout the period of illness were very significant to their health conditions. Some previous studies revealed that attention to nutrition in PLWHA still lack whereas the urgency and positive impact of nutrition interventions for PLWHA have been demonstrated [6]. The nutritional conditions of PLWHA who are vulnerable and fluctuate require a nutritional assessment more comprehensive so that PLWHA have a preventive effect that will improve their health conditions. Hence, this study intended to assess the nutritional status among PLWHA and understanding the relationship between nutritional status and health characteristics among HIVIAIDS patients.

\section{Methods}

\section{Study design \\ A cross-sectional analytical design was used} to undertaken the study.

\section{Sample and settings}

The target population was all the outpatient recorded in Kemuning Poly, Bandung General Hospital since November 2017 by 350 of PLWHA. A purposive sampling method was used using the following inclusion criteria: (1) Age >18 years, (2) not currently pregnant, and (3) undergoing ART. The number of samples needed after being calculated using the Slovin formula was 78 respondents.

\section{Instrument}

The instruments of this study divided into three parts were the sociodemographic, health characteristic, and nutritional status. The sociodemographic characteristics included age, gender, marital status, education level, occupation, and household income. The health characteristic questionnaire included length of HIV diagnosed, staging of HIV, level of stress, and type of ART. The nutritional status of this study was measures using weight scales $(\mathrm{kg})$ and tape to measure upper arm circumference (cm). The classified of nutritional status divided into three categories: (1) Body mass index (BMI) which consists into three levels was underweight $(\leq 18.4)$, normal (18.5-25.0), and obese ( $\geq 25.0$ ); (2) Mid-upper arms circumstances (MUACs) consist into two levels which were at risk $(<23.5)$, not risk $(\geq 23.5 \mathrm{~cm})$; and (3) energy intake which consists into three levels was high intake $(>80 \%)$, moderate intake $(51-79 \%)$, and low intake $(<51 \%)$.

\section{Data analysis}

Descriptive statistics (frequency and percentage) were used to analyze and describe sociodemographic, health characteristic, and nutritional status. The cross-tabulation calculations used Chi-square $\left(\chi^{2}\right)$ were presented to identify the relationship between nutritional status and health characteristics.

Table 1: Sociodemographic characteristics of HIVIAIDS patients in Bandung general hospital $(n=78)$

\begin{tabular}{lll}
\hline Sociodemographic characteristics & $\mathrm{f}$ & $\%$ \\
\hline Age & & \\
19-39 & 49 & 62.8 \\
40-49 & 29 & 37.2 \\
Gender & 66 & \\
$\quad$ Male & 12 & 84.6 \\
$\quad$ Female & & 15.4 \\
Marital status & 12 & 15.4 \\
$\quad$ Married & 60 & 76.9 \\
Single & 6 & 7.7 \\
Widowed & & \\
Education level & 3 & 3.8 \\
$\quad$ Primary school & 11 & 14.1 \\
Junior high school & 34 & 43.6 \\
Senior high school & 30 & 38.5 \\
$\quad$ College/university & & \\
Occupation & 16 & 20.5 \\
$\quad$ Unemployed & 11 & 14.1 \\
Students & 51 & 65.4 \\
Employed & & \\
Household income & & 52.6 \\
$\quad$ IDR 2,500,000 & & 47.4 \\
\hline IDR 2,500,000 & 37 & \\
\hline
\end{tabular}

\section{Ethical consideration}

This study was approved by the Ethics Commission of the Health Faculty of Medical Faculty of Padjadjaran University, number: 94/UN6.KEP/EC/2018 and a research permit from the Bandung City 
General Hospital number: 070/1168.C-RSUD/18 and was conducted retrieval of data in the Bandung City Regional General Hospital, Bandung City in January-February 2018.

\section{Results}

\section{The sociodemographic characteristics and health characteristics of PLWHA}

Data were collected in total of 78 PLWHA with majority of the respondents ranging from 19 to 39 years old

Table 2: Health characteristics of HIVIAIDS patients in Bandung general hospital $(n=78)$

\begin{tabular}{|c|c|c|}
\hline Health characteristics & $f$ & $\%$ \\
\hline \multicolumn{3}{|l|}{ Length of HIV (+) diagnoses } \\
\hline$\leq 6$ months & 16 & 20.5 \\
\hline$>6$ months & 62 & 79.5 \\
\hline \multicolumn{3}{|l|}{ WHO clinical stage } \\
\hline Stage I & 48 & 61.5 \\
\hline Stage II & 9 & 11.5 \\
\hline Stage III & 9 & 11.5 \\
\hline Stage IV & 12 & 15.5 \\
\hline \multicolumn{3}{|l|}{ Stress/Trauma } \\
\hline No stress & 74 & 94.9 \\
\hline Mild (gastrointestinal inflammation, cancer) & 4 & 5.1 \\
\hline \multicolumn{3}{|l|}{ ART } \\
\hline $\begin{array}{l}\text { First choice (combination of tenofovir, lamivudine/emtricitabine, and } \\
\text { efavirenz) }\end{array}$ & 65 & 83.3 \\
\hline Alternative choice & 13 & 16.7 \\
\hline
\end{tabular}

(62.8\%). Majority of respondents were male (84.6\%) and single $(76.9 \%)$. Regarding education was senior high school level $(43.6 \%)$. Most of the respondents were employed $(65.4 \%)$ and more than half of them had household income less than $\leq$ IDR 2,500,000 (52.6\%) (Table 1).

In terms of health characteristics, majority of respondent had the length of HIV diagnosed more than 6 months $(79.5 \%)$, clinical WHO Stage I $(61.5 \%)$, no stress level $(94.9 \%)$, and first choice of ART $(83.3 \%)$ (Table 2).

\section{The nutritional statues of PLWHA}

Concerning nutritional status of PLWHA majority of the respondents had normal BMI (18.5-25) $(61.5 \%)$ and MUAC not at risk $(>23.5 \mathrm{~cm})(71.8 \%)$, and most of the respondents had moderate level of energy intake $(37.2 \%)$ (Table 3).

Table 3: Nutritional status of HIVIAIDS patients in Bandung general hospital $(n=78)$

\begin{tabular}{lll}
\hline Nutritional status & $\mathrm{f}$ & $\%$ \\
\hline BMI & 24 & 30.8 \\
$\quad$ Underweight $(\leq 18.4)$ & 48 & 61.5 \\
$\quad$ Normal $(18.5-25.0)$ & 6 & 7.7 \\
$\quad$ Obese $(\geq 25.0)$ & & \\
MUAC & 22 & 28.2 \\
$\quad$ At risk $(<23.5)$ & 56 & 71.8 \\
$\quad$ Not risk $(\geq 23.5 \mathrm{~cm})$ & 26 & 33.3 \\
Energy intake & 29 & 37.2 \\
$\quad$ High intake $(>80 \%)$ & 23 & 29.5 \\
$\quad$ Moderate intake $(51-79 \%)$ & & \\
Low intake $(<51 \%)$ &
\end{tabular}

The nutritional statues based on the health characteristic among PLWHA PLWHA

$B M I$ based on the health characteristic among

The health characteristics based on nutritional status of BMI, are shown in Table 4. The majority of respondents who had length of HIV diagnose less than 6 months had normal BMI (68.8\%). Normal BMI was higher among respondents who had the WHO clinical stage stadium I $(68.8 \%)$ compare to Stage II $(55.6 \%)$, Stage III (44.4\%), and Stage IV (58.3\%). Respondents with normal $\mathrm{BMI}$ also higher among respondents had no level stress $(63.5 \%)$ and ART was alternative choice (76.9\%). All health characteristics (time since HIV diagnosis, clinical WHO stage, stress level, and ART) had no significant $(p$-value $=0.431 ; 0.131 ; 0.596 ; 0.122)$ relationship with nutritional status (Body Mass Index-BMI) (Table 4).

\section{MUAC based on the health characteristic among PLWHA}

The nutritional status of MUAC did not have significant impacts on the health characteristics of respondents. with Respondents with category of MUAC were not significant among health characteristic of respondents with had length of HIV diagnose.

The majority of respondents with category of MUAC not at risk had length of HIV diagnose less than 6 months $(75 \%)$ compared with respondents who had length of HIV diagnose more than 6 months $(71 \%)$ and there was not significant relationship $(p=0.749)$. Respondents with category of MUAC not at risk were higher among respondents who had the WHO clinical stage stadium II (77.8\%) compared with stadium I (75\%), stadium III (55.6\%), stadium IV (66.7\%) and there was not significant associated $(p=0.630)$. Similarly, respondents with no stress had higher MUAC not at risk category $(63.5 \%)$ compared with respondents with mild stress $(50 \%)$ revealed not significant relationship $(p=0.320)$. Likewise, respondents who had ART in alternative choice of ART category had higher not at risk in nutritional status MUAC (84.6\%) compared to respondents who had ART in first choice category (69.2\%) and there was not significant relationship $(p=0.260)($ Table 5$)$.

\section{Energy intake based on the health} characteristic among PLWHA

No significant relationship was found between the health characteristics of respondents (time since HIV diagnosis, clinical WHO stage, stress level, and ART treatment) and energy intake. The results showed that half of the respondents were moderate energy intake $(50 \%)$ based on their health characteristic who had length of HIV diagnose less than 6 months compared with respondents who had length of HIV diagnose more than 6 months $(33.9 \%)(p=0.485)$. More than half of 
Table 4: Status of nutrition BMI based on the health characteristic of HIVIAIDS patients in Bandung general hospital $(n=78)$

\begin{tabular}{|c|c|c|c|c|c|}
\hline \multirow[t]{2}{*}{ Health characteristic } & \multicolumn{3}{|l|}{ BMI } & \multirow[t]{2}{*}{$\chi^{2}$-value } & \multirow[t]{2}{*}{$\mathrm{p}$-value } \\
\hline & Underweight f (\%) & Normal f (\%) & Obese f $(\%)$ & & \\
\hline \multicolumn{6}{|l|}{ Length of $\mathrm{HIV}(+)$ diagnoses } \\
\hline$\leq 6$ months & $5(31.3)$ & $11(68.8)$ & $0(0)$ & \multirow[t]{2}{*}{1.682} & \multirow[t]{2}{*}{0.431} \\
\hline$>6$ months & $18(29.0)$ & $38(61.3)$ & $6(9.7)$ & & \\
\hline \multicolumn{6}{|l|}{ Stadium } \\
\hline Stage I & $9(18.8)$ & $33(68.8)$ & $6(12.5)$ & \multirow[t]{4}{*}{9.854} & \multirow[t]{4}{*}{0.131} \\
\hline Stage II & $4(44.4)$ & $5(55.6)$ & $0(0)$ & & \\
\hline Stage III & $5(55.6)$ & $4(44.4)$ & $0(0)$ & & \\
\hline Stage IV & $5(41.7)$ & $7(58.3)$ & $0(0)$ & & \\
\hline \multicolumn{6}{|l|}{ Stress } \\
\hline No stress & $21(28.4)$ & $47(63.5)$ & $6(8.1)$ & \multirow[t]{2}{*}{1.036} & \multirow[t]{2}{*}{0.596} \\
\hline Mild (gastrointestinal inflammation, cancer) & $2(50)$ & $2(50)$ & $0(0)$ & & \\
\hline \multicolumn{6}{|l|}{ ART } \\
\hline First choice & $22(33.8)$ & $39(60)$ & $4(6.2)$ & \multirow[t]{3}{*}{4.207} & \multirow[t]{3}{*}{0.122} \\
\hline Alternative choice & $1(7.7)$ & 10 (76.9) & $2(15.4)$ & & \\
\hline Total & $23(29.5)$ & $49(62.8)$ & $6(7.7)$ & & \\
\hline
\end{tabular}

BMI: Body mass index.

the respondents were moderate energy intake (55.6\%) based on the WHO clinical stage stadium III (55.6\%) compared with stadium I (37.5\%), stadium II (22.2\%), and stadium IV $(33.3 \%)(p=0.597)$. The level of moderate energy intake of respondents between no stress (37.8\%) compared to mild stress respondents $(25 \%)$ ( $p$-value $=$ $0,651)$. Similarly, majority of respondents were moderate energy intake based on first choice ART (41.5\%) compared with respondents who had alternative choice in ART category $(15.4 \%)(p=0,051)$ (Table 6).

\section{Discussion}

The regulation of Minister of Health No. 87 in 2014 concerning guidelines for ART states that nutrition services are part of a treatment support package for PLWHA. Monitoring and evaluating the nutritional status of PLWHA must be carried out regularly and promptly given appropriate nutritional interventions if there is a risk or sign of a decrease in nutritional status. Good nutritional status has a positive effect on increasing CD4 levels in the blood, this can be explained by the protective effect of fat cells or adipose which is a source of the leptin hormone. The leptin hormone is known to inhibit the detrimental/damaging effects of cytokines whose levels are increased in HIV patients [9]

The findings of this study showed that the majority of respondents were male, range at young age between 19 and 39 years, single, employed status with more than half of them had household income less than $\leq$ IDR 2,500,000. Under the Indonesian characteristic, these characteristics were congruent with a previous study that the major of PLWHA are male, level of education was senior high school, and employed status [10], [11].

Table 3 shows that the majority of respondents were normal BMI (61.5\%) and they were not at risk of MUAC (71.8\%). However, there were still respondents who had BMI below normal (30.8\%). Similarly, the results of MUAC measurements revealed the risk of chronic energy shortages in $28.2 \%$ of respondents. These results were not much different from the study conducted by NLP et al. (2016) at Cipto Mangunkusumo Hospital (n $=444$ ); the percentage of patients with $\mathrm{BMI}<18.5 \mathrm{~kg} / \mathrm{m}^{2}$ was $32.4 \%$. In addition, research conducted by Iskandar et al. [13] at Hasan Sadikin General Hospital, Bandung ( $n=281$ ), showed similar results with the percentage of HIV patients having a BMI <18.5 kg/m² $(25.7 \%)$.

Decreased nutritional status among PLWHA can be caused by several factors, including: Poor food security; drug-nutrition interactions; diarrhea and vomiting; decreased metabolism and nutrient absorption; and increasing energy needs. The diagnosed of HIV can cause damage to the intestine by making the intestinal villi thinner and decreasing D-xylose absorption. This condition causes disruption of absorption of carbohydrates and fats. Thus reducing the effectiveness of fat-soluble vitamins, such as vitamins $A$ and $E$, which are important in the formation of body immunity [14], [15].

Table 5: Status of nutrition (MUAC) based on the health characteristic of HIVIAIDS patients in Bandung general hospital $(n=78)$

\begin{tabular}{|c|c|c|c|c|}
\hline \multirow[t]{2}{*}{ Health characteristic } & \multicolumn{2}{|l|}{ MUAC } & \multirow[t]{2}{*}{$\chi^{2}$-value } & \multirow[t]{2}{*}{$p$-value } \\
\hline & At risk $\mathrm{f}(\%)$ & Not risk f (\%) & & \\
\hline \multicolumn{5}{|l|}{ Length of HIV (+) diagnoses } \\
\hline$\leq 6$ months & $4(25)$ & $12(75)$ & \multirow{2}{*}{0.102} & \multirow[t]{2}{*}{0.749} \\
\hline$>6$ months & $18(29)$ & $44(71)$ & & \\
\hline \multicolumn{5}{|l|}{ Stadium } \\
\hline Stage I & $12(25)$ & $36(75)$ & \multirow[t]{4}{*}{1.731} & \multirow[t]{4}{*}{0.630} \\
\hline Stage II & $2(22.2)$ & $7(77.8)$ & & \\
\hline Stage III & $4(44.4)$ & $5(55.6)$ & & \\
\hline Stage IV & $4(33.3)$ & $8(66.7)$ & & \\
\hline \multicolumn{5}{|l|}{ Stress } \\
\hline No stress & $20(27)$ & $54(63.5)$ & \multirow[t]{2}{*}{0.989} & \multirow[t]{2}{*}{0.320} \\
\hline Mild (gastrointestinal inflammation, cancer) & $2(50)$ & $2(50)$ & & \\
\hline \multicolumn{5}{|l|}{ ART } \\
\hline First choice & $20(30.8)$ & $45(69.2)$ & \multirow[t]{3}{*}{1.266} & \multirow[t]{3}{*}{0.260} \\
\hline Alternative choice & $2(15.4)$ & $11(84.6)$ & & \\
\hline Total & $22(28.2)$ & $56(71.8)$ & & \\
\hline
\end{tabular}


Table 6: Status of nutrition (energy intake) based on the health characteristic of HIV/AIDS patients in Bandung general hospital ( $\mathrm{n}=\mathbf{7 8}$ )

\begin{tabular}{|c|c|c|c|c|c|}
\hline \multirow[t]{2}{*}{ Health characteristic } & \multicolumn{3}{|c|}{ Energy intake } & \multirow[t]{2}{*}{$\chi^{2}$-value } & \multirow[t]{2}{*}{$p$-value } \\
\hline & High f (\%) & Moderate $\mathrm{f}(\%)$ & Low $\mathrm{f}(\%)$ & & \\
\hline \multicolumn{6}{|l|}{ Length of HIV (+) diagnoses } \\
\hline$\leq 6$ months & $4(25)$ & $8(50)$ & $4(25)$ & \multirow[t]{2}{*}{1.447} & \multirow[t]{2}{*}{0.485} \\
\hline$>6$ months & $22(35.5)$ & $21(33.9)$ & $19(30.6)$ & & \\
\hline \multicolumn{6}{|l|}{ Stadium } \\
\hline Stage I & $18(37.5)$ & $18(37.5)$ & $12(25)$ & \multirow[t]{4}{*}{4.596} & \multirow{4}{*}{0.597} \\
\hline Stage II & $4(44.4)$ & $2(22.2)$ & $3(33.3)$ & & \\
\hline Stage III & $1(11.1)$ & $5(55.6)$ & $3(33.3)$ & & \\
\hline Stage IV & $3(25)$ & $4(33.3)$ & $5(41.7)$ & & \\
\hline \multicolumn{6}{|l|}{ Stress } \\
\hline No stress & $25(33.8)$ & $28(37.8)$ & $21(28.4)$ & \multirow[t]{2}{*}{0.858} & \multirow[t]{2}{*}{0.651} \\
\hline Mild (gastrointestinal inflammation, cancer) & $1(25)$ & $1(25)$ & $2(50)$ & & \\
\hline \multicolumn{6}{|l|}{ ART } \\
\hline First choice & $18(27.7)$ & $27(41.5)$ & $20(30.8)$ & \multirow[t]{3}{*}{5.934} & \multirow[t]{3}{*}{0.051} \\
\hline Alternative choice & $8(61.5)$ & $2(15.4)$ & $3(23.1)$ & & \\
\hline Total & $26(33.3)$ & $29(37.2)$ & $23(29.5)$ & & \\
\hline
\end{tabular}

The higher of clinical stage, the greater the proportion of respondents who were in the underweight nutrition status and at risk of UMAC. Increasing the body's needs related to the disease burden lead to inadequate nutrient intake at the WHO Stages III and IV will cause a more progressive decrease in nutritional status. Research conducted by Tesfamariam et al. (2016), showed similar results, patients in Stages III and IV were found to be twice as likely to experience undernutrition [16].

This study revealed that the majority of PLWHA were WHO clinical Stage I $(61.5 \%)$, no stress level $(94.9 \%)$, and the nutritional status was normal of BMI (63.5\%). A study conducted by Thapa et al. (2015), reported that the $\mathrm{WHO}$ clinical staging has significant effect on nutrition status [17]. This finding also supported by a study done in Ethiopia that reported that the malnutrition was usually met with at the advanced staging of HIV infection [6]. In addition, the level of psychological status was significantly associated with the nutritional status among PLWHA. The increase of depression among PLWHA can affect their appetite, intake of nutrition, and exacerbate the status of nutrition [18], [19].

The respondents in this study showed that the most widely used combination of ART was the first choice combination consisting of tenofovir, lamivudine/emtricitabine, and efavirenz. Based on the research of Hussen et al. (2017), the provision of ART in patients with $\mathrm{BMI}<18.5 \mathrm{~kg} / \mathrm{m}^{2}$ increases the risk of opportunistic infections and the administration of combination ART on a zidovudine basis increases the risk of opportunistic infections which also decreases nutritional status [20].

In accordance with [21], the poor treatment outcomes can be predicted by assessing nutrient intake. Failure to increase nutrient intake will result in increased disease severity in the presence of immunosuppression. Another result of study from Utarini et al. [22] also explained that there were several predictors in nutritional status fluctuations in health characteristic of PLWHA, including BMI, CD4 count, clinical stage, status of diarrhea, and nutrient intake. It is known that nutrient intake was the strongest predictor to be able to improve nutritional status in PLWHA. The low nutritional status cannot be underestimated, PLWHA with IMT values $\leq 18.5 \mathrm{~kg} / \mathrm{m}^{2}$, MUAC $\leq 25 \mathrm{~cm}$, CD4 count $\leq 350 \mathrm{cells} / \mu \mathrm{l}$, and suPAR levels plasma $>5.3 \mathrm{ng} / \mathrm{ml}$ are more rapid to experience death [23]. Similarly, all the variables of the status of nutrition in this study were no significant effect on all variables of health characteristics among PLWHA. Here, the majority of respondent has not severe health condition include WHO staging I, no stress level, and first choice of ART. Thus, the nutritional status in this study reported the normal of BMI, not risk of MUAC, and moderate level of energy intake.

\section{Conclusion}

The study of health characteristic and nutritional status of PLWHA revealed that the high prevalence of health characteristics was the length of HIV diagnosed more than 6 months, clinical WHO Stage I, no stress level, and first choice of ART. Regarding to nutritional status of PLWHA, majority of the respondents had normal BMI, MUAC not at risk, and moderate level of energy intake. There was not significant associated between all the variables of nutrition status and health condition among PLWHA. The good condition of health characteristic among PLWHA in this study impacted on level the nutritional status.

\section{References}

1. World Health Organization. Policy Brief: Consolidated Guidelines on HIV Prevention, Diagnosis, Treatment and Care for Key Populations. Geneva: World Health Organization; 2017.

2. CDC Directorate General, EH, Ministry of Health of Indonesia. Laporan situasi Perkembangan HIV-AIDS di Indonesia JanMaret 2017. Jakarta, Indonesia: Ministry of Health of Indonesia; 2018.

3. Zhang C, Li X, Liu Y, Zhou Y, Shen Z, Chen Y. Impacts of HIV stigma on psychosocial well-being and substance use 
behaviors among people living with HIVIAIDS in China: Across the life span. AIDS Educ Prev. 2018;30(2):108-19. https://doi. org/10.1521/aeap.2018.30.2.108

\section{PMid:29688775}

4. Ibrahim K, Kombong R, Sriati A. The difference of perceived HIV stigma between people living with HIV infection and their families. Nurse Media J Nurs. 2019;9(2):117-27. https://doi. org/10.14710/nmjn.v9i2.24256

5. Travaglini LE, Himelhoch SS, Fang LJ. HIV stigma and its relation to mental, physical and social health among Black women living with HIVIAIDS. AIDS Behav. 2018;22(12):3783-94. https://doi. org/10.1007/s10461-018-2037-1

PMid:29417351

6. Gebremichael DY, Hadush KT, Kebede EM, Zegeye RT. Food insecurity, nutritional status, and factors associated with malnutrition among people living with HIVIAIDS attending antiretroviral therapy at public health facilities in West Shewa Zone, Central Ethiopia. Biomed Res Int. 2018;2018:1913534. https://doi.org/10.1155/2018/1913534

PMid:29854730

7. Colecraft E. HIVIAIDS: Nutritional implications and impact on human development. Proc Nutr Soc. 2008;67(1):109-13. https:// doi.org/10.1017/s0029665108006095 PMid:18234139

8. Hamzeh B, Pasdar Y, Darbandi M, Majd S, Mohajeri SR Malnutrition among patients suffering from HIV/AIDS in Kermanshah, Iran. Ann Trop Med Public Health. 2017;10(5):1210. https://doi.org/10.4103/atmph.atmph_315_17

9. Wicaksana R. Hubungan antara indeks massa tubuh dengan jumlah CD4 pada penderita HIV yang Mendapat Pengobatan ARV. Maj Kedokt Bandung. 2015;47(4):237-41. https://doi. org/10.15395/mkb.v47n4.623

10. Januraga PP, Reekie J, SKom TM, Lestari BW, Iskandar S, Wisaksana $\mathrm{R}$, et al. The cascade of HIV care among key populations in Indonesia: A prospective cohort study. Lancet HIV. 2018;5(10):e560-8. https://doi.org/10.1016/ s2352-3018(18)30148-6

11. Nyamathi AM, Shin SS, Sinha S, Carpenter CL, Garfin DR, Ramakrishnan P, et al. Sustained effect of a community-based behavioral and nutrition intervention on HIV-related outcomes among women living with HIV in rural India: A quasi-experimental trial. J Acquir Immune Defic Syndr. 2019;81(4):429-38. https:// doi.org/10.1097/qai.0000000000002044 PMid:30973547

12. Rahayu NL, Karjadi TH, Nelwan EJ, Rumende CM. Faktorfaktor yang berhubungan dengan tertundanya inisiasi terapi antiretroviral pada pasien dengan infeksi human immunodeficiency virus. J Penyakit Dalam Indones. 2016;3(3):151-7. https://doi.org/10.7454/jpdi.v3i3.26

13. Iskandar $\mathrm{S}$, de Jong CA, Hidayat $\mathrm{T}$, Siregar IM, Achmad TH, van Crevel R, et al. Successful testing and treating of HIV/ AIDS in Indonesia depends on the addiction treatment modality. J Multidiscip Healthc. 2012;5:329.

PMid:23293529
14. Sudfeld CR, Mugusi F, Muhihi A, Aboud S, Nagu TJ, Ulenga $N$, et al. Efficacy of vitamin $\mathrm{D}(3)$ supplementation for the prevention of pulmonary tuberculosis and mortality in HIV: A randomised, double-blind, placebo-controlled trial. Lancet HIV. 2020;7(7):e463-71. https://doi.org/10.1016/ s2352-3018(20)30108-9

15. Thuppal SV, Jun S, Cowan A, Bailey RL. The nutritional status of HIV-infected US adults. Curr Dev Nutr. 2017;1(10):e001636. https://doi.org/10.3945/cdn.117.001636 PMid:29955683

16. Tesfamariam K, Baraki N, Kedir H. Pre-ART nutritional status and its association with mortality in adult patients enrolled on ART at Fiche Hospital in North Shoa, Oromia region, Ethiopia: A retrospective cohort study. BMC Res Notes. 2016;9(1):1-9. https://doi.org/10.1186/s13104-016-2313-y PMid:27998310

17. Thapa R, Amatya R, Pahari DP, Bam K, Newman MS. Nutritional status and its association with quality of life among people living with HIV attending public anti-retroviral therapy sites of Kathmandu Valley, Nepal. AIDS Res Ther. 2015;12(1):14. https://doi.org/10.1186/s12981-015-0056-9 PMid:25937825

18. Ibrahim K, Kurnia Y, Rahayuwati L, Nurmalisa BE, Fitri SU. Hubungan antara fatigue, jumlah CD4, dan kadar hemoglobin pada pasien yang terinfeksi human immunodeficiency virus (HIV). J Keperawatan Padjadjaran. 2018;5(3):649. https://doi. org/10.24198/jkp.v5i3.649

19. Weldehaweria NB, Abreha EH, Weldu MG, Misgina KH. Psychosocial correlates of nutritional status among people living with HIV on antiretroviral therapy: A matched case-control study in Central zone of Tigray, Northern Ethiopia. PLoS One. 2017;12:e0174082. https://doi.org/10.1371/journal.pone.0174082 PMid:28301592

20. Hussen S, Belachew T, Hussein N. Nutritional status of HIV clients receiving HAART: Its implication on occurrence of opportunistic infection. Open Public Health J. 2017;10(1):208-14. https://doi. org/10.2174/1874944501710010208

21. Chen YN, Wall KM, Fofana K, Navarro-Colorado C. Nutrition indicators as potential predictors of AIDS-defining illnesses among ARV-naïve HIV-positive adults in Kapiri Mposhi, Zambia 2008-2009. PLoS One. 201914(7):e0219111. https://doi. org/10.1371/journal.pone.0219111 PMid:31265479

22. Utarini GA, Sawitri AA, Merati TP. Predictors of improved nutritional status among HIVIAIDS patients who received antiretroviral therapy (ART) at Sanglah General Hospital Denpasar. Hemoglobin (Median). 2017;11(1):96. https://doi. org/10.15562/phpma.v5i2.30

23. Pereira M, Magno L, da Silva Gonçalves L, Dourado I. HIV infections and food insecurity among pregnant women from low-and middle-income countries: A systematic review and meta-analysis. AIDS Behav. 2021;25(10):3183-93. https://doi. org/10.1007/s10461-021-03280-2

PMid:33903996 